\title{
Reducing Your Risk for Cancer: The Power of Food ${ }^{1}$
}

\author{
Jodi Fitzgerald, Danielle Nelson, Madison Woodard, and Jeanette Andrade ${ }^{2}$
}

\section{Overview of Cancer}

Cancer is the second leading cause of death within the United States. Two out of every 5 people will be diagnosed with some form of cancer within their lifetime (Kochanek et al. 2016). Forty-five percent of cancer deaths may have been caused by risk factors that you can change (National Cancer Institute 2017), such as weight, diet, and lifestyle. This publication describes the modifiable risk factors for cancer and tips to reduce your risk for cancer.

\section{Risk Factors for Cancer}

\section{Weight}

Health professionals determine if one is at a healthy weight based on the Body Mass Index (BMI). BMI is calculated using your height and weight. People who are considered to be at a healthy body weight have a lower risk for many types of cancer, such as breast, colon, and prostate. Extra weight alone contributes to 1 out of every 5 cancer-related deaths within the United States (American Cancer Society 2017).

\section{Diet}

According to the World Cancer Research Fund (2018), your dietary habits may contribute to the risk of cancer if you:

- Eat more than 3 servings (3-4 ounces) of red or processed meats (e.g., luncheon meats, hotdogs) each week.

- Eat meats that are fried, broiled, smoked, grilled, or charred (well done).
- Eat low amounts of fruits, vegetables, and whole grains.

\section{Lifestyle}

Certain lifestyle behaviors may increase your risk for cancer, such as:

- Smoking: Tobacco, in all forms, is the number-one preventable cause of cancer.

- Alcohol: Drinking more than 2-3 drinks per day increases one's risk for colon, stomach, and liver cancer (World Cancer Research Fund 2018).

\section{Reducing Your Risk for Cancer Start Simple}

Set a goal each week to make small changes towards health, such as:

- Choose at least 1 piece of fruit daily for a week.

- Cook at least 1 meal that is prepared with beans, vegetables, and whole grains this week.

- Eat a $1 / 2$ cup of legumes daily for a week.

Eat more fruits, vegetables, beans/lentils and whole grains. These foods are:

- High in vitamins, minerals, and antioxidants.

- High in fiber.

- Low in saturated fat.

1. This document is FSHN20-36, one of a series of the Food Science and Human Nutrition Department, UF/IFAS Extension. Original publication date August 2020. Visit the EDIS website at https://edis.ifas.ufl.edu for the currently supported version of this publication.

2. Jodi Fitzgerald, MD; Danielle Nelson, MD, MPH, assistant professor and assistant medical director, University of Florida Department of Community Health and Family Medicine; Madison Woodard, undergraduate student, Food Science and Human Nutrition Department; Jeanette Andrade, assistant professor and director, MS-DI program, Food Science and Human Nutrition Department; UF/IFAS Extension, Gainesville, FL 32611.

The Institute of Food and Agricultural Sciences (IFAS) is an Equal Opportunity Institution authorized to provide research, educational information and other services

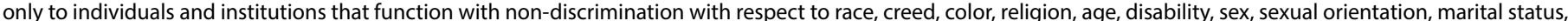

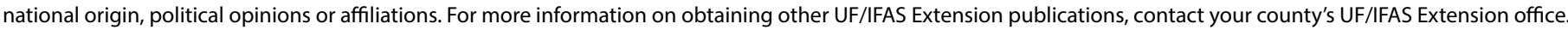
U.S. Department of Agriculture, UF/IFAS Extension Service, University of Florida, IFAS, Florida A \& M University Cooperative Extension Program, and Boards of County Commissioners Cooperating. Nick T. Place, dean for UF/IFAS Extension. 
Choosing these foods will help you to be at a healthy body weight and will lower your risk for many types of cancer.

Refer to Table 1: What and How Much to Eat in Each Food Group below for further information.

\section{Setting Yourself Up for Success}

- Use the suggested recipes in this publication for ideas and inspiration for healthy eating.

- Start making changes with a friend or family member! It can be helpful to have support.

- Ask for help from a health professional, such as a registered dietitian, to make those positive changes.

Table 1. What and How Much to Eat from Each Food Group.

\begin{tabular}{|c|c|c|c|}
\hline Food Group & Amount to Eat Daily & Focus & Reasons \\
\hline Grains & $\begin{array}{l}6-8 \text { ounces } \\
1 \text { ounce }=1 \text { slice of bread; } 1 / 2 \\
\text { cup cooked pasta/rice; } 1 \frac{12 \text { cup }}{\text { cooked cereal }}\end{array}$ & $\begin{array}{l}\text { Whole grains: whole-wheat } \\
\text { breads, whole-wheat/buckwheat } \\
\text { pasta, rolled old-fashioned oats, } \\
\text { brown rice, lentils, amaranth, } \\
\text { bulgur, quinoa, farrow, and barley }\end{array}$ & $\begin{array}{l}\text { Whole grains have more nutrients and fiber than } \\
\text { refined grains, such as white bread, white rice, and } \\
\text { white pasta. }\end{array}$ \\
\hline Fruits & $\begin{array}{l}\text { At least } 1.5-2 \text { cups } \\
1 \text { cup equivalent = } 1 \text { cup raw } \\
\text { or cooked fruit }\end{array}$ & & $\begin{array}{l}\text { Frozen fruits preserve nutrients. } \\
\text { Include a variety of colors in your dishes to obtain } \\
\text { the vitamins and minerals you need. } \\
\text { Juice does not have as much fiber as fresh/frozen } \\
\text { fruit. }\end{array}$ \\
\hline Vegetables & $\begin{array}{l}\text { At least } 2.5-3 \text { cups } \\
1 \text { cup equivalent }=1 \text { cup raw } \\
\text { or cooked vegetable, } 2 \text { cups } \\
\text { leafy salad greens }\end{array}$ & & $\begin{array}{l}\text { Frozen vegetables preserve the nutrients. Save } \\
\text { money by buying in season. }\end{array}$ \\
\hline Dairy & $\begin{array}{l}3 \text { cups } \\
1 \text { cup equivalent }=1 \text { cup } \\
\text { milk, yogurt, or fortified soy } \\
\text { milk; } 1 \frac{112 \text { ounces natural }}{\text { cheese, such as cheddar, or }} \\
2 \text { ounces of processed cheese }\end{array}$ & $\begin{array}{l}\text { Drink } 2 \% \text {, reduced-fat, or fat-free } \\
\text { milk, and eat yogurt and cheese. }\end{array}$ & $\begin{array}{l}\text { Rich source of calcium and vitamin D to help build } \\
\text { strong bones. }\end{array}$ \\
\hline Protein & $\begin{array}{l}5-6.5 \text { ounces } \\
1 \text {-ounce equivalent }=1 \\
\text { ounce lean meat, poultry, or } \\
\text { seafood; } 1 \text { egg; } 1 / 4 \text { cup cooked } \\
\text { beans or tofu; } 1 \text { tbsp peanut } \\
\text { butter; } 1 \frac{1}{2} \text { ounce nuts or seeds }\end{array}$ & & $\begin{array}{l}\text { Red and processed meats may increase your risk } \\
\text { for heart disease. }\end{array}$ \\
\hline
\end{tabular}

\section{References}

American Cancer Society. ACS Guidelines for Nutrition and Physical Activity, 2017. Accessed 10/10/2018. https:// www.cancer.org/healthy/eat-healthy-get-active/acsguidelines-nutrition-physical-activity-cancer-prevention/ guidelines.html

Kochanek, K. D., S. L. Murphy, J. Q. Xu, and E. Arias. 2017. Mortality in the United States, 2016. NCHS Data Brief, no. 293. Hyattsville, MD: National Center for Health Statistics.

National Cancer Institute. 2017. Obesity and Cancer. Accessed 10/10/2018. Primary source: Flegal, K. M., B. K. Kit, H. Orpana, and B. I. Graubard. 2013. "Association of All-Cause Mortality with Overweight and Obesity Using Standard Body Mass Index Categories: A Systematic Review and Meta-analysis." JAMA 309 (1): 71-82.
US Department of Agriculture. 2016. "10 Tips: Make better beverage choices." https://www.choosemyplate.gov/ ten-tips-make-better-beverage-choices

US Department of Health and Human Services and US Department of Agriculture. 2015. 2015-2020 Dietary Guidelines for Americans. 8th Edition. https://health.gov/our-work/ food-and-nutrition/2015-2020-dietary-guidelines/

World Cancer Research Fund/American Institute for Cancer Research. 2018. Diet, Nutrition, Physical Activity and Cancer: A Global Perspective. Continuous Update Project Expert Report. https://www.wcrf.org/dietandcancer 


\section{Breakfast}

\section{Rolled Oats with Your Favorite}

Toppings

Prep time: 1 minute

Cook time: Microwave 3 minutes OR Stove-top, 7 minutes

Makes 1 Serving

\section{Ingredients:}

- $1 / 2$ cup rolled oats (sometimes called old-fashioned oats)

- 1 cup water or reduced-fat milk

\section{Preparation:}

1. Combine water (or milk), oats in a 2-cup microwavable bowl.

2. Microwave on high for $2 \frac{1}{2}$ to 3 minutes.

OR

1. Bring water (or milk) to a boil in a small saucepan.

2. Stir in $1 / 2$ cup oats and turn heat down to medium; cook the oats for 5 minutes, while stirring.

3. Remove from the heat, cover and let stand for 2 to 3 minutes before eating.

\section{Optional toppings:}

- Fresh fruits

- Cinnamon

- Vanilla

- Add protein by adding 1 tbsp of nuts or seeds-try chia seeds, flax seeds, almonds, or pecans.

- If you must add sweetness, try using 1 teaspoon of maple syrup, brown sugar, or dried fruits.

\section{Lunch}

Mediterranean Chickpea Salad

Prep time: 15 minutes

Cook time: 0 minutes

Makes 4 servings

\section{Ingredients:}

- 1 can of chickpeas (garbanzo beans), rinsed and drained

- 1 red bell pepper chopped

- 1 yellow bell pepper chopped

- 1 green bell pepper chopped

- $1 / 2$ small red onion chopped

- About 15 grape tomatoes cut into halves

- 1 medium cucumber sliced and quartered

- $1 / 3$ cup pitted Kalamata olives (optional)

- 1 tbsp olive oil

- 2 tbsp fresh or bottled lemon juice

- 2 tsp minced garlic

- 1 tsp dried oregano

- freshly ground pepper, to taste

\section{Preparation:}

1. Place all salad ingredients into a large bowl and toss to combine.

2. Taste and add salt and pepper as you'd like.

3. Place in refrigerator for 1 hour to marinate or serve immediately. Salad is best enjoyed within 2-3 days after making. Try making a large batch and eating for lunch tomorrow or as a side dish with dinner.

\section{Dinner}

\section{Black Bean Soup}

Prep time: 10 minutes

Cook time: 15-20 minutes

Makes 6 servings

\section{Ingredients:}

- 2 cans black beans

- 1 can chicken broth

- $1 / 2$ cup salsa or diced tomatoes

- 1 tbsp chili powder

- 1 tsp garlic powder

\section{Optional Toppings}

- 6 tbsp onion (any kind)

- 3 tbsp cilantro

- $1 / 2$ avocado

- $1 / 2$ tbsp nutritional yeast for cheesy flavor

\section{Preparation:}

1. Mash one can of beans with a potato masher, blender, or large spoon.

2. Pour both cans of beans into medium saucepan.

3. Add chicken broth, salsa, and chili powder.

4. Bring to a boil and cook for $15-20$ minutes, or until soup is slightly thickened.

5. Top each serving with avocado, cilantro, onions, and nutritional yeast if desired.

Try doubling the recipe and freezing a few portions for quick meals later! 


\section{Breakfast}

\section{Granola with Fruit}

Prep time: 5 minutes

Cook time: 0 minutes

Makes 1 Serving

\section{Ingredients:}

- 1 apple, banana, or peach

- $1 / 2$ cup granola or rolled oats

\section{Optional Toppings}

- Almond, cashew, or coconut milk

- Add protein by adding 1 tbsp of nuts of seeds-try chia seeds, flax seeds, almonds, or pecans.

- If you must add sweetness, try using 1 tsp or less of maple syrup, brown sugar, or dried fruits.

\section{Preparation:}

1. Chop fruit into small pieces.

2. Add granola to bowl and top with fresh fruit. Add other toppings to your taste.

\section{Lunch}

Black Bean \& Corn Wraps

with Cucumber, Tomato, and

Avocado Salad

Prep time: 15 minutes

Cook time: 0 minutes

Makes 4 Servings

Wrap ingredients:

- 2 cans of black beans

- 1 cup of frozen corn

- $1 / 2$ cup of salsa

- 1 tsp of garlic powder

- 1 tsp of cumin

- 1 tsp of onion powder

- 4 whole-wheat tortillas

\section{Salsa ingredients:}

- 1 cucumber

- 1 tomato

- 2 avocados

- 1 lime (or squeeze of juice)

\section{Preparation:}

1. Rinse and drain two cans of black beans.

2. Add beans to a pot and place in frozen corn.

3. Make salsa. Chop cucumber, tomato, and avocados into small cubes. Toss with lime juice.

4. Mix the salsa, garlic powder, cumin, and onion powder into the bean and corn mixture.

5. Cook until beans and corn are warmed.

6. Warm tortillas for 10 seconds in microwave if desired.

7. Place beans and corn inside tortillas, top with more salsa, and wrap up.

\section{Dinner}

\section{Garlic Ginger Soup}

Prep time: 15 minutes

Cook time: 30 minutes

Makes 4 Servings

\section{Ingredients:}

- $8 \mathrm{oz}$ rice noodles, buckwheat noodles, or whole-wheat noodles

- 1 red bell pepper

- 8 cups of low sodium vegetable broth

- 6 one-inch pieces of ginger, peeled and smashed

- 5 tsp minced garlic

- 1 block of extra-firm tofu, drained and pressed

- 4 tbsp of low-sodium soy sauce

- 8 tsp of lemon juice

- 1 tsp of sriracha or red pepper

- $1 / 4$ a cup of chopped cilantro

- 1 tbsp of ground ginger

- 1 tbsp of garlic powder

- 1 package frozen edamame

\section{Preparation:}

1.Dice tofu into small squares.

2. Add tofu, bell pepper, garlic powder, and ginger powder to a nonstick pan. Cook until tofu is brown.

3. In a pot, add broth, ginger pieces, and garlic. Bring to a boil and then turn down to low heat.

4. Add soy sauce, sriracha, lemon juice, frozen edamame, and cilantro to pot. Cover and continue to simmer.

5.In a separate pot, cook rice noodles according to directions on package.

6. Add cooked noodles, tofu, bell peppers, and cilantro to the broth. Let sit covered for 5 mins. 


\section{Breakfast}

\section{4-Ingredient Breakfast Bars}

Prep time: 10 minutes

Cook time: 30 minutes

Makes 6-9 Servings

\section{Ingredients:}

- Olive oil or butter (for pan)

- 2 large, very ripe bananas OR 1 regular-size can of pure pumpkin. If using bananas, wait until the bananas are soft and covered with brown spots.

- 2 cups old-fashioned rolled oats

- $1 / 4-1 / 2$ cup flax seeds

- 1 tsp vanilla extract

Optional Additions:

- $1 / 4$ cup pitted, chopped dried dates or dried blueberries

- $1 / 2$ tsp nutmeg or cinnamon

- 1 tbsp brown sugar

\section{Preparation:}

1. Heat oven to $350^{\circ} \mathrm{F}$. Lightly coat a $9 \times 9$ baking pan with olive oil or butter. You can use any size baking pans you have if you are cooking in bulk.

2. Peel the bananas and mash them in a bowl. If you have a blender or mixer, you can use it.

3. Stir the oats, vanilla, flax seeds, and other ingredients into the mix.

4. When recipe is cool, cut into squares.

Try making a few pans of this to store in your freezer for grab-and-go breakfast and snackbars!

\section{Lunch}

Hummus \& Veggie Sand wich

Prep time: 10 minutes

Cook time: 0 minutes

Makes 4 Servings

\section{Hummus Ingredients:}

- 1 tbsp lemon juice

- 1 can no-salt-added or lowsodium white beans (like cannellini) (drained, rinsed)

- 3 tbsp water

- $1 / 4$ tsp paprika (normal, smoked, or sweet)

- $1 / 4$ tsp black pepper

\section{Wrap Ingredients:}

- $1 / 3-1 / 2$ cup hummus

- 4 whole-wheat tortilla wraps or 8 slices whole-wheat bread or wholegrain crackers

- 1 handful lettuce, washed

- 1 cucumber, sliced

- 1 green bell pepper, sliced

- 1 avocado, optional

\section{Preparation:}

1. Toss all ingredients into a food processor and blend until smooth, or mash in large bowl with potato masher.

2. Spread $1 / 3-1 / 2$ cup hummus per serving on bread, crackers, or wraps. Layer on the vegetables and enjoyor serve crackers and vegetables with hummus as a dip.

\section{Dinner}

Balsamic Glazed Tofu, Vegetables, and Sweet Potato Wedges

Prep time: 15 minutes

Cook time: 40 minutes

Makes 4 Servings

\section{Ingredients:}

Vegetables

- 3-4 cups sliced squash of choice

- 1-2 cups bell peppers, mushrooms, or green beans

\section{Sweet Potatoes}

- 3 sweet potatoes washed, scrubbed, and cut into 1" slices

- $1 / 2$ tsp minced garlic

- 1 tbsp olive oil

- $1 / 4$ tsp dried thyme

- $1 / 8$ tsp red pepper

\section{Tofu ingredients}

- $1 \mathrm{lb}$ (16 oz.) extra-firm tofu

- 3 tbsp balsamic vinegar

- 1 tsp Italian seasoning

\section{Preparation:}

1. Heat oven to $400^{\circ} \mathrm{F}$.

2. Prepare tofu: Place tofu on a plate. Place another plate on top of the tofu with a few books on top and let sit for 45 minutes. Cut into 1 -inch cubes and mix with other ingredients. Spread on baking sheet.

3. Mix sweet potatoes and spices in a bowl and spread on baking sheet.

4. Spread vegetables on baking sheet and sprinkle with oil, salt, and pepper.

Bake pans of sweet potatoes, tofu, and vegetables for 15 minutes. Flip and return to oven for another 15 minutes. 


\section{Fresh/Frozen Foods}

Avocado (Pick one that is not completely firm and not yet squishy.)

Bananas

Cucumber

Extra-firm tofu

Fresh fruit (for snacks and for oatmeal)

Fresh ginger

Frozen corn

Frozen shelled edamame (soybeans)

Grape tomatoes

Green beans (ends trimmed)

Green peppers

Lemons (or sub lemon juice)

Mushrooms

New potatoes

Red peppers

Small red onion

Yellow pepper

\section{Optional}

Cilantro

\section{Dry Goods}

$\square$ Canned black beans

$\square$ Canned chickpeas/garbanzo beans

$\square$ Canned no-salt-added or low-sodium white beans (like cannellini)

Chicken broth

Dried fruit (for trail mix and for oatmeal)

Rice noodles, buckwheat noodles, or whole-wheat noodles

Rolled oats or old-fashioned oats

Salsa (or you can use your leftover grape tomatoes)

Vegetable broth

$\square$ Whole-wheat tortillas or pita bread

\section{Optional}

$\square$ Granola

Kalamata olives

Pumpkin (or ripe bananas)

\section{From Your Pantry}

Balsamic vinegar

Chili powder

Cinnamon

Cumin

Dried thyme

Garlic powder

Ground ginger powder

Italian seasoning spice mix

Minced garlic

Olive oil

Oregano

Nondairy milk (almond, cashew, or coconut)

$\checkmark$ Nuts (walnuts, almonds, pecans, or cashews)

Salt and pepper

Seeds (flax and/or chia seeds)

Sriracha sauce or ground red pepper

Vanilla

\section{Optional}

$\square$ Nutritional yeast

Ground paprika (smoked or regular)

\section{Find more recipes at these websites}

American Cancer Society https://www.cancer.org/healthy/eat-healthy-get-active/eat-healthy/find-healthy-recipes.html MyPlate Recipe Guides www.choosemyplate.gov/recipes-cookbooks-and-menus 